\title{
Chinese NGOs in action against HIV/AIDS
}

\author{
Hua XU ${ }^{1, *}$, Yi ZENG ${ }^{1,2}$, Allen F ANDERSON ${ }^{3}$ \\ ${ }^{1}$ The US-China AIDS Alliance Foundation, Beijing100029, China \\ ${ }^{2}$ Institute of Virology, Chinese Academy of Preventive Medicine, Beijing 100052, China \\ ${ }^{3}$ School of Public and Environmental Affairs, Indiana University, Bloomington, Indiana 47405-1701, USA
}

\begin{abstract}
Chinese nongovernmental organizations (NGOs) have played a significant role in the battle against AIDS in the People's Republic of China. This article provides a brief overview of the structure of these organizations, as well as an analysis of their principle accomplishments. Of great significance in this analysis is the fact that Chinese NGOs have effectively dealt with many sensitive health education areas that government authorities have felt reluctant to handle directly. As such, they have provided an indispensable component in the HIV/AIDS prevention and control calculus on the mainland.
\end{abstract}

Keywords: HIV/AIDS, NGO, health education, health intervention.

\section{INTRODUCTION}

The AIDS epidemic continues its seemingly inexorable spread throughout the world. It is now very clear that the virus represents not only a medical problem, but also a challenging and multifaceted social problem. Because of this fact, it is imperative that nongovernmental organizations outside of, or tangential to, the medical arena become involved in prevention and control efforts. The Chinese government is supportive of the development of such organizations on the mainland, and has recognized the key role that they can play against the deadly virus. Vice Premier Wu Yi stated that "we should mobilize all the partners in the society to participate in the fight against HIV/AIDS. We need to improve our policies and strategies to build a better environment for all forces in the society to participate in the response, and to try our best to facilitate the involvement of all sectors [1]." It was found early on in the epidemic in China that NGOs could deal with many sensitive health education interventions that the government felt reluctant to handle directly. As a result, nongovernmental organizations on the mainland that are focused on HIV issues are growing in both number

*Correspondence: Hua XU

Tel: 86-10-64225073; Fax: 86-10-64225072;

E-mail: xuhua20012001@yahoo.com and impact.

There are currently over fifty large NGOs involved in AIDS control. These large organizations can be divided into two groups. The first group is composed of mass organizations such as, inter alia, the All China Women's Federation, the All China Youth League, the Red Cross, the All China Federation of Trade, and the Chinese Working Committee for Caring for the Younger Generation. Each of these organizations has branches at different levels throughout China, and most of their work is done by professional social workers. The second group is composed of professional civil groups such as the Chinese Association of Medicine, the Chinese Association of Preventive Medicine, the China Family Planning Association, the Chinese Foundation for the Prevention of STD \& AIDS (CFPSA), and the Chinese Association of STD/AIDS Prevention and Control (CASAPC), among others. The organizations in this group typically have branches at the provincial level, and most of their work is conducted by medical and public health personnel.

The number of small NGOs is even greater, and includes such organizations as the "Home for Loving Care" in Beijing, the "Mangrove Support Group", the "Love Care Family" in Wenxi county of Shanxi Province, the "Health Club" in Jilin City of Jilin Province, and the "Chengdu Gay Community Care Organization" in Sichuan Province. Most of their work is conducted by volunteers and persons living 
with HIV/AIDS.

Whatever their levels, most Chinese AIDS NGOs get their financial support from the government and international organizations; however, many also get support from social donations.

\section{SPECIFIC AREAS OF ACTIVITY AND IMPACT}

Since the first case of AIDS was discovered on the mainland in 1985, Chinese NGOs have played a key role in prevention and control efforts. Associated activities fall into the following categories.

\section{Health education}

Without a vaccine or cure for HIV/AIDS, educational interventions are especially important in the prevention and control of the disease. Chinese NGOs have assisted government at various levels to develop policy and material for health education. Successes have been achieved in the broad dissemination of AIDS prevention knowledge, as well as antidiscrimination education. Specific activities have included:

1) Various AIDS education booklets, pamphlets, and videos have been produced. For example, the educational video "AIDS Track" was produced by the CFPSA and disseminated nationwide. This video was awarded a Special Prize by the Chinese Ministry of Public Health. The video "Warning of the Century" was also produced by the CFPSA and aired on CCTV in 1999. During 2001, the CFPSA cooperated with the Beijing Television Station in airing a quiz show in which high school students competed in answering questions about HIV/AIDS.

2) During 1994, five national newspapers ran an STD/ AIDS knowledge competition in which more than one million people participated.

3) In cooperation with local governments, the CFPSA held large-scale AIDS exhibitions in Guangzhou and Nanning during December, 1997, and May, 1998. With the support of the Ministry of Health, the CFPSA and the CASAPC collaborated in holding a large AIDS exhibition in Beijing during December, 1998. More than 200,000 people attended these exhibitions [2]. Thereafter, this exhibition format was expanded to many other provinces and cities. More than 500,000 people were exposed to prevention and control knowledge.

4) AIDS information campaigns for railway workers was developed by the CASAPC and implemented along the Beijing-Hong Kong, Beijing-Ulaanbaatar, and KunmingPingxiang railway lines.

5) Peer education for young people was developed in Yunnan Province and expanded to other provinces.

6) The CFPSA cooperated with the governments and health departments in the Weifang region of Shandong Province, especially the cities of Shouguang and Zhucheng, to develop a large-scale and multifaceted HIV/AIDS campaign for rural areas. This was accomplished using the following approach:

a. A leadership group that included the governmental head of the county and heads of departments concerned with STD/HIV/AIDS prevention and control was established in every county in the region;

b. Health professionals and social workers who were to be involved in survey and education efforts were trained;

c. Knowledge, attitude, and practice surveys were conducted prior to the design of the educational interventions;

d. In light of survey findings, multifaceted educational interventions were developed and implemented at the county and township levels;

e. Thereafter, intervention assessments were conducted. Preliminary results showed a coverage rate of the target population of 90 percent (about 100,000 persons), and the HIV/AIDS awareness rate rose from 35 percent to 60 percent. This inspired the Weifang region governmental leadership continue to build the region into a model area for HIV/AIDS prevention and control [3].

7) China's principle mass organizations are members of the State Council AIDS Working Committee, and have actively joined in the response against HIV/AIDS. The All China Women's Federation and the All China Youth League, in cooperation with the Ministry of Health, conducted a "Face to Face" publicity campaign that targeted women and yong people in China Cares program sites. In 2003, the "Youth Red Ribbon" program supported 250 training workshops, knowledge contests, and plays. It also printed and distributed 1,100,000 copies of twenty-six different types of educational materials. The All China Federation of Trade Unions AIDS added education into the training of its members. For example, education on general sanitation and health care were supplemented with AIDS Education. By the end of 2003, more than 8,000 lecture courses had been conducted for over one million participants.

8) Since the early 1990s, the Chinese Family Planning Association (CFPA) has paid special attention to AIDS prevention, and has taken an active part in the work of prevention and control. The CFPA has made great strides in IEC work, and has conducted a series of educational activities in diverse groups, ranging from Family Planning Association members, young people, and farmers to those in the floating (migrant) population, active military personnel, and service providers in entertainment establishments. Through these interventions, the CFPA has gained great experience in disseminating HIV/AIDS prevention knowledge. 


\section{Professional training and communication}

Chinese NGOs organized various training courses and symposia on both sexually transmitted diseases and HIV/ AIDS, and published journals to increase the professional knowledge of health system personnel. These activities included:

1) The China International Symposium on AIDS in Beijing was hosted by the China Academy of Traditional Chinese Medicine and the CFPSA during December, 1995;

2) The CASAPC produced educational materials for a ten province campaign, developed a training course on AIDS prevention and control for counselors on the mainland, and developed a training course on AIDS program management for Hong Kong;

3) During 1996, the CASAPC developed a television film entitled "The Same World. The Same Hope" to educate viewers about HIV/AIDS, and organized a national level workshop on AIDS diagnosis and treatment;

4) In 1997, the CASAPC jointed Hong Kong-mainland seminar on AIDS, and created an anti-AIDS campaign along the Beijing-Hong Kong railway line;

5) In 2001, the CASAPC assisted the Ministry of Health in organizing China's first large-scale AIDS conference, which attracted more than 1000 participants.

6) From 2003 to 2005, four workshops on HIV/AIDS surveillance and diagnosis were organized for health professionals and workers in the systems of the Ministry of Health. Ministry of Justice and Ministry of Public Security in Jilin City, Baoding, Dalian, and Chengdu by the CFPSA and local Centers for Disease Control and Prevention. These workshops were supported by the University of Illinois at Chicago, Fogarty AITRP, the University of Nebraska, and the US-China AIDS Alliance Foundation;

7) An International Medical Forum on Infectious Disease was held in Beijing by the CASAPC;

8) The Working Committee of the Caring for the Younger Generation organization held several seminars and training classes at various governmental levels that included HIV/ AIDS prevention and control knowledge. The trainees included cadres from various governmental units at the county, town, and village levels.

9) The CASAPC held a national symposium during 2004 on the China-UNICEF Cooperation Project on AIDS Prevention and Control;

10) The Chinese Journal for STD and AIDS Prevention and Control was started in 1995 by the CASAPC. The Journal on International Information on STD and AIDS went into publication in 1996. AIDS prevention and treatment information and advice on STDs and AIDS was posted on the internet, and the website "AIDS On Line" was established in November, 2001.

\section{Social mobilization}

Chinese NGOs have worked actively to involve all sectors of society in prevention and control efforts. These activities include:

1) With the support of over thirty Chinese ministries and national departments, forty-seven national civil associations, forty-one media organizations, and representative from international organizations such as UNAIDS an the World Health Organization, the CFPSA launched the "121 Joint Action Plan" on March 28, 2003. The goal of the plan is to foster governmental and nongovernmental cooperation so that social resources can be utilized in an efficient and effective manner in fighting HIV/AIDS. The Joint Action Plan received broad social acceptance and media acclaim. National level scientists and academicians from the Chinese Academy of Sciences, the Chinese Academy of Engineering, and leaders from industry and commerce participated in activities that raised public awareness of both AIDS and the need for broad social involvement in battling the epidemic. On December 1, 2003, a celebration was held in the Great Hall of the People in that recognized the achievements of, the Joint Action Plan. Both ZHOU Tienong, the Vice Chairman of the CCPCC, and WU Jieping, the Vice Chairman of the Standing Committee of the $9^{\text {th }}$ NPC were in attendance. Individuals and organizations that had made donations to the plan were awarded certificates of merit. In January, 2004, the plan was recognized as being among the "Top 10 Public Relations Events in China During 2003."

2) From 2000 to 2005, the CFPSA engaged celebrities in literature and art as goodwill ambassadors. Among these individuals were film stars JIANG Wenli and LIU Xin, and singers Kris PHILLIPS, ZHENG Xulan, ZHANG Huamin, and CAI Guoqing. These artists played a major role in publicizing AIDS knowledge, offering care and solace to orphans and persons living with HIV/AIDS, sending a message of nondiscrimination to the broader public, and conducting other AIDS-related activities.

\section{Behavioral interventions and research targeting high risk populations}

Over the years, Chinese NGOs have employed various mechanisms to carry out interventions among high risk populations; indeed, most needle exchange programs, interventions targeting drug users and men who have sex with men (MSM), and the promotion and distribution of condoms have been conducted by, or involved, Chinese NGOs.

1) The Chinese Preventive Medicine Association (CPMA) has been involved in HIV/AIDS prevention and control since 1995. The CPMA implemented a condom promotion project, sponsored by the World Health 
Organization, among high risk populations. This was the first condom distribution project in China.

2) The promotion and distribution of condoms at STD clinics in Shanghai and Henan Province was started in 1996.

3) Behavioral investigations of commercial sex workers and long-distance truck drivers in Yunnan Province and Inner Mongolia were conducted in 1995 and 1997.

4) An intervention targeting the drug user population in Liangshan Prefecture in Sichuan Province was conducted in 1998.

5) The CASAPC conducted interventions among intravenous injection drug users, commercial sex workers, MSM, and migrants.

\section{The AIDS network}

Four joint meetings for NGOs on HIV/AIDS prevention and control were held in Beijing (1995), Zhuhai (2000), Harbin (2003), and Congqing (2005). At these meetings, NGO representatives from across China shared prevention and treatment information. At the first meeting, a Code of Action was passed by thirty-six organizations, including the CASAPC, the CFPSA, the Chinese Association of Medicine, the Chinese Association of Preventative Medicine, the China Family Planning Association, and the All China Women's Federation [4]. The code was reviewed and revised at subsequent meetings.

\section{Care for people living with AIDS and AIDS orphans}

Chinese NGOs have given great attention to the problems of social discrimination against people living with HIV/AIDS and AIDS orphans.

1) The CFPSA and the Shanxi Provincial Health Department developed an educational intervention in Xia County during August-December, 2001. A preliminary assessment indicated a target population coverage rate of 90 percent, and a rise in the HIV/AIDS awareness rate from $5.7 \%$ to $34.6 \%$. The awareness rate on HIV/AIDS transmission modes was raised from $41.2 \%$ to $81.1 \%$. The awareness rate on HIV/AIDS non-transmission modes was raised from $12.32 \%$ to $45.07 \%$. Thereafter, local NGOs in Xia County established a "Love Care Home" for people living with HIV/AIDS [5].

2) The Working Committee of the "Caring for the Younger Generation" organization investigated the mental health status, general quality of life, and educational status of AIDS orphans in Henan, Shanxi, and Yunnan provinces. On the $16^{\text {th }}$ World AIDS Day, the Working Committee and UNICEF held a joint seminar on "Caring for Orphans Affected by HIV/AIDS.” Chinese state leaders, officials from UNICEF, and principals from relevant Chinese ministries attended the seminar and appealed to the public to be attentive to the living conditions of affected orphans.
3) The CASAPC developed care and support programs for cities and counties in twelve provinces and the cities of Beijing and Shanghai.

4) The Home of Loving Care has long been recognized for its care and treatment of people with HIV/AIDS, as well as its prevention and control efforts. Through the Home of Loving Care, those with AIDS have received medical care, disease consultation, guidance, and psychological support. It is a true bridge between people with HIV/AIDS and the broader society.

5) More and more people living with HIV/AIDS are willing to publicize their status and participate in prevention and control activities. These individuals develop self-help groups and assist in antiretroviral treatment education.

6) International NGOs also play an important role in antiretroviral and opportunistic infection treatment in China.

7) The Positive Art Workshop (PAW) was established by persons living with HIV/AIDS in December, 2002. PAW activities include art events, interactive exhibitions in China and abroad, charity fundraisers, and AIDS awareness events. Of particular importance is their effort to document on film and still photography images that capture the hopes, fears, frustrations, and ideas for the future held by persons living with HIV/AIDS.

8) XIA Shuqing, a woman from rural Jilin Province in northeast China, was infected with HIV in 2001. Initially despondent about her conditions, she received help from a local NGO. Thereafter, she actively participated in AIDSrelated activities, and organized a health club for others infected with HIV in her area. This club serves as a place for study, communication, mutual support, and self-help activities. In 2004, under the sponsorship of the CFPSA, Mrs. Xia attended the Chinese NGO satellite forum at the $15^{\text {th }}$ International AIDS Conference in Bangkok and made a presentation to those in attendance. United Nations Secretary General Kofi Annan called her a hero in the fight against AIDS.

\section{International exchange}

Chinese NGOs have carried out many collaborative programs on AIDS prevention and control with international counterparts.

1) Chinese NGOs actively participate in international AIDS conferences.

2) Chinese NGOs participated in the AIDS meeting for Northeast Asian Countries in November, 2000. Those in attendance shared experiences in fighting the virus and strengthened their spirit of cooperation and common purpose.

3) During the $15^{\text {th }}$ International AIDS Conference in Bangkok, Chinese NGOs successfully organized various programs, including an NGO forum with the theme 
"Exchange, Cooperation, Friendship, and Facing the Challenge Together." More than 300 participants attended the forum, and heard key-note speeches by Dr. WANG Longde, the Vice-Minister of the Ministry of Health of the PRC, and Dr. Peter Piot, Executive Director of UNAIDS. The press reported that this was the first time that Chinese NGOs had made such a strong statement about HIV/AIDS.

4) The $7^{\text {th }}$ International Congress on AIDS in Asia and the Pacific was held in Kobe, Japan, on 1-5 July, 2005. During the Congress, a Chinese NGO symposium on HIV/ AIDS prevention and control was held in the International Conference Center on the evening of 2 July 2005. This symposium was organized by the CFPSA, the CASAPC, and the Hong Kong AIDS Foundation. Financial support was obtained from numerous internal and external organizations and individual donators. Drs. Wang and Piot also attended this session and gave keynote addresses to more than 100 delegates from around the world. Members of vulnerable populations from the mainland, Hong Kong, and Taiwan also made presentations. A Chinese NGO exhibition was also held in the NGO exhibition area of the Congress. The news media once again noted the active role that Chinese NGOs are taking in the battle against HIV/AIDS.

5) At the UN Special Assembly on AIDS on 2 June 2005, Vice-Minister Wang Long-de praised the contributions made by Chinese NGOs and others who are working hard against AIDS on the mainland. He encouraged the all sectors to participate in the battle. He stated that China is at a critical juncture in the battle against AIDS, and Chinese NGOs are key players in the effort. Indeed, he concluded that Chinese NGOs are "becoming an indispensable force in AIDS prevention and control [6]."

\section{CHALLENGES FOR THE FUTURE}

In spite of the successes of Chinese NGOs in preven- tion and control efforts, several changes in approach need to be addressed:

1) Chinese NGOs need a greater focus on capacity building.

2) Chinese NGOs need increased financial investment.

3) There is a need for more NGOs to participate in AIDS programs.

4) There is a need for more cooperation and less competition between Chinese NGOs.

5) There is a need for greater cooperation between government sectors and Chinese NGOs to avoid duplication of effort or gaps in coverage.

These changes will help to insure that the invaluable role that Chinese NGOs have played in the battle against AIDS will not only be maintained, but will actually grow in importance and impact.

\section{REFERENCES}

1 A Joint Assessment of HIV/AIDS Prevention, Treatment, and Care in China. Jointly prepared by the State Council AIDS Working Committee Office and the UN Theme Group on HIV/AIDS in China. 2004.

$2 \mathrm{Xu} \mathrm{H}$, Anderson AF, Xu XH. AIDS knowledge exhibitions as an effective way to spread AIDS knowledge. Proceedings of the XIII International AIDS Conference, Durban, South Africa. 2000.

$3 \mathrm{Xu} \mathrm{H}$, Zeng Y, Xu H, et al. "Developing Health Education on STD/AIDS Prevention Through Using Multi-Kind and MultiSector Methods is an Effecdtive Way to Address the AIDS Epidemic," AIDS and Common Hygiene, China Medical Publishing House 2005: 160-8.

4 Wang GY. "Chinese NGOs will Jointly Fight HIV/AIDS," Chinese AIDS Prevention and Treatment 1995; 1:62-3.

$5 \mathrm{Xu} \mathrm{H}$. "Strengthening Interventions on HIV/AIDS and Creating an Environment without Discrimination against PLWHA in Risk Areas" Poster, XIV International AIDS Conference, Barcelona, Spain. 2002.

6 Wang LD. Presentation at the Chinese NGO Symposium at the CAAP, Kobe, Japan, 1-5 July 2005. 